\title{
El simbolismo del agua en Pleamar de vejez del escritor costarricense Jorge Marín
}

\author{
María Isabel Barboza Ramírez \\ Universidad de Costa Rica, Costa Rica \\ mbarboza14@hotmail.com \\ https://orcid.org/0000-0002-3222-1225
}

Recibido: 4 de febrero 2018

Aceptado: 30 de mayo 2018

\section{Resumen:}

El presente estudio realiza un recorrido por las distintas manifestaciones y representaciones que a través de la historia ha tenido el elemento "agua" y su importancia en la historia de la humanidad. Especialmente, en el texto de Jorge Marín, poeta costarricense, se analiza la representación simbólica de este elemento presente a lo largo del poemario. El eje temático que cruza los diversos poemas se centra en dos grandes universales en la literatura: vida/muerte y la asociación del agua que el sujeto lírico establece con respecto a esta isotopía.

Palabras clave: agua; representación simbólica; vida; muerte; vejez.

\section{Water symbolism in the work Pleamar de vejez by costarican writer Jorge Marín}

\section{Abstract:}

The following study makes an analysis through the different historical representations and manifestations of water and its importance to mankind. Notably, in the poems written by Jorge Marín, the symbolic representation of this element is analyzed trough his work. The main theme of the poem collection is based in two recurrent topics in literature: life and death and the association with the water element that the lyrical subject establishes regarding this isotopy.

Key words: water; symbolic representation; life; death; old age.

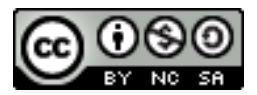

La Revista Estudios es editada por la Universidad de Costa Rica y se distribuye bajo una Licencia Creative Commons Atribución-NoComercial-CompartirIgual 3.0 Costa Rica. Para más información envíe un mensaje a 
El agua como elemento singular ha tenido a través de la historia de la humanidad diferentes simbolismos. Así en muchas religiones cristianismo, islamismo, judaísmo, budismo entre otros, se asocia a un estado de purificación y redención. Desde la biblia se cita como fuente de vida y de creación "y el espíritu de Dios se movía sobre la faz de las aguas" (Genésis:1.2).

Los ríos, la lluvia, los estanques, los lagos, los glaciares, las granizadas o la nieve constituyen las diversas manifestaciones que puede adoptar el agua al interpretarse e incorporarse en las esferas culturales y religiosas. En la literatura en general constituye uno de los grandes arquetipos, diversos autores lo abordan como elemento constituyente de sus narraciones, por ejemplo, muy presente en la literatura costumbrista o realista latinoamericana y me atrevo a decir que de la literatura universal. Desde una perspectiva psicoanalítica Jung, Freud, Lacan, entre otros; han desarrollado complejas teorías desde el mundo de la ensoñación y el inconsciente sobre las representaciones del agua en sus diversas manifestaciones, por ende, de ella devienen una serie de simbolismos y polisemia.

Asimismo, dos terceras partes de nuestro cuerpo están revestidas de agua, esencialmente vivimos en dependencia de este elemento que sin lugar a dudas forma parte indispensable de la vida cotidiana. Se parte así, de la idea preconcebida de que el agua limpia y purifica el cuerpo. No obstante, desde las más antiguas culturas se asocia el agua a la vida y a la muerte, dos grandes universales ampliamente abordados en literatura. En los textos bíblicos, por ejemplo, se cita el diluvio simbólicamente como fuerza destructora, avasalladora: "Porque dentro de siete días haré llover sobre la tierra cuarenta días y cuarenta noches, y borraré de la faz de la tierra a todo ser viviente que he creado" (Génesis $7: 4)$.

\section{(C) $(00$}

La Revista Estudios es editada por la Universidad de Costa Rica y se distribuye bajo una Licencia Creative Commons Atribución-NoComercial-CompartirIgual 3.0 Costa Rica. Para más información envíe un mensaje a 
Especial: Naturaleza amena y naturaleza agreste en las letras hispánicas

Como arquetipo universal todos los pueblos han tenido experiencias o vivencias de ser una fuerza destructora y a la vez regeneradora. El diluvio es una representación simbólica de catástrofe que se convierte de igual forma en amenaza para el hombre.

Así, el agua constituye sustancia de vida y de muerte. El inconsciente trabaja sobre la esperanza del paso del agua como fuente purificadora llevándose lejos a la muerte.

M. Eliade (1978) señala al respecto:

La purificación por el agua tiene esas mismas propiedades; en el agua todo se «disuelve», toda «forma» se desintegra, toda «historia» queda abolida; nada de lo que ha existido hasta entonces subsiste después de una inmersión en el agua: ningún perfil, ningún «signo», ningún «acontecimiento». La inmersión equivale, en el plano humano, a la muerte, y en el plano cósmico, a la catástrofe (diluvio), que disuelve periódicamente al mundo en el océano primordial. Por desintegrar toda forma y abolir toda historia, poseen las aguas esa virtud de purificación, de regeneración y de renacimiento; todo lo que en ella se sumerge «muere», y sale de las aguas como un niño sin pecado y sin «historia», apto para recibir una nueva revelación y comenzar una nueva vida «limpia». (p.86)

Por tanto, Eliade hace referencia a las propiedades del agua como fuerza disolvente, que pude destruir, aniquilar; pero de igual forma en sentido humano es fuerza de renovación y de purificación como ocurre para el hinduismo en el Río Ganges, donde la inmersión adquiere precisamente ese valor simbólico de limpieza para el alma y para cuerpo.

Bajo esta aparente e indivisible relación que da origen al simbolismo del agua en vida/muerte, abordaré el análisis de la obra del escritor costarricense Jorge Marín Guzmán, Pleamar de vejez (2014). Este poemario escrito en versos octosílabos,

La Revista Estudios es editada por la Universidad de Costa Rica y se distribuye bajo una Licencia Creative Commons Atribución-NoComercial-CompartirIgual 3.0 Costa Rica. Para más información envíe un mensaje a 
Especial: Naturaleza amena y naturaleza agreste en las letras hispánicas constituye un ejemplo de poesía clásica costarricense y un canto elegíaco a la vejez.

Ya el título mismo enuncia al mar como símbolo de agua. Así, la RAE define "pleamar" como "fin o término de la creciente del mar". En otras palabras, pleamar es el lugar donde el mar pierde fuerza, y precede la calma. El sujeto lírico pone de manifiesto un preámbulo al diálogo entre vida / muerte con el lector. Asimismo, alude a la vejez como antesala de la muerte.

La barca, el navío naufragante representan la llegada de esa vejez. El mar, fuente de agua, a su vez simboliza la muerte, camino que todo ser recorrerá algún día.

Los ríos, la corriente, los arroyos, las marismas, los diluvios, la tormenta son los diferentes significantes que aparecen en el poemario y aluden simbólicamente al agua como elemento del proceso dicotómico de vida/muerte. Tal y como se observa en los siguientes versos:

aparece a la deriva

mi navío que naufraga

con el agua tempestuosa

y el oleaje de infortunio,

cuando avanzo por las sombras

de los años urticantes

que le agrega desencantos a mi cuerpo envejecido (p. 45)

Del poema "Encuentro" señalo los siguientes versos:

Encuentro que las tormentas

Con sus fríos y neblinas

Deterioran el sendero

De mi vida ilusionada. (p.17)

En los anteriores versos se observa el agua como fin, termino y paso de una vida.

El sujeto lírico va experimentando ese fin de la existencia que se acerca

La Revista Estudios es editada por la Universidad de Costa Rica y se distribuye bajo una Licencia Creative Commons Atribución-NoComercial-CompartirIgual 3.0 Costa Rica. Para más información envíe un mensaje a revistaestudios.eeg@ucr.ac.cr. 
Especial: Naturaleza amena y naturaleza agreste en las letras hispánicas

inexorablemente, la vejez en sentido precario y desafortunado, en el cual el cuerpo va sufriendo el pasar del tiempo, un tiempo que no regresa, que no se detiene como el agua, la corriente, las marismas y otras alusiones que el sujeto lírico va elaborando a lo largo del poemario. Se crea así, ars poética, dado por un metalenguaje, manifiesto en las diferentes vivencias de ese yo lírico en relación con la metáfora del agua. La construcción metafórica del agua presente en el poemario lleva un recorrido por las diversas representaciones que el líquido adquiere: lluvia, pozo, gotas, burbujas, entre otros.

\section{EL AGUA COMO CONTINUUM}

El poema "Ardientes llamaradas" refleja claramente el paso de la corriente en la que se envuelve la vida y avanza sin remedio hacia su final. El agua constituye para el sujeto lírico la sucesión, el río, el mar, la corriente que sigue, fluye a través de los años, a través del tiempo. Asimismo, la vejez es representada como un caudal, que va recorriendo el curso incesante del agua.

Avanzan por la corriente

De los ríos y los mares

Los murmullos que no cesan

De vagar sobre las olas,

$Y$ descienden en mi mente

Los desvelos y el insomnio

Que en silencio me lastiman

Con sus látigos del tiempo. (p.125)

La corriente, igualmente, simboliza pérdida de años, es el inconsciente en el espejo, que tritura la vida con el paso del tiempo y que va dejando atrás el pasado. El agua se convierte para el sujeto lírico en la decadencia, el recuerdo, casi como una pesadilla en la que la vida no se detiene, por tanto, el agua también constituye

\section{(c) (i) (2) (2)}

La Revista Estudios es editada por la Universidad de Costa Rica y se distribuye bajo una Licencia Creative Commons Atribución-NoComercial-CompartirIgual 3.0 Costa Rica. Para más información envíe un mensaje a 


\section{Especial: Naturaleza amena y naturaleza agreste en las letras hispánicas}

fuerza, continuum en el más estricto sentido de la palabra. Un continuum que lacera, lástima porque el agua presencia de vida corre como el tiempo. La comparación entre agua y tiempo establecen de forma metafórica lo que sucede con el cuerpo, que se deteriora, que pierde poco a poco vida, esperanza. Ambos elementos agua y tiempo comparten su estado natural, es decir, la propiedad de lo continuo, de lo incesante. El sujeto lírico establece esta relación para manifestar lo que ocurre con el ser humano cuando se va acercando irremediablemente a la vejez. Del poema "Después" cito:

La concha de los pesares, de los vientos y la noche, en la arena se lamenta de los mares ondulados,

Al dejarle sus recuerdos de cansadas ilusiones sobre espumas que fallecen en las olas del agobio. (p.65)

El agua, asimismo representa el descenso, la caída, el abismo. Los recuerdos, las ilusiones van quedando atrás, fallecen con el fluir de la vida que es corriente de agua. El parangón deriva precisamente de la relación que establece el sujeto lírico entre la corriente del agua y el paso de la vida, simbolizada con la llegada de la senectud. Prevalecen en los versos de Marín la impotencia ante la naturaleza que es avasalladora como el agua, doblega al cuerpo, cambia, transforma la piel, las manos, los ojos, la cara, entre otros.

Del poema "Como un telón" cito:

"Hoy recibo las edades que reflejan los ocasos en la noche sin estrellas en la noche de penumbras cuando siento las fisuras

La Revista Estudios es editada por la Universidad de Costa Rica y se distribuye bajo una Licencia Creative Commons Atribución-NoComercial-CompartirIgual 3.0 Costa Rica. Para más información envíe un mensaje a 
Especial: Naturaleza amena y naturaleza agreste en las letras hispánicas

en mi piel y mi corteza, donde anidan las miserias, las molestias y el tormento." (p.57)

\section{EL AGUA COMO VIDA/MUERTE}

Es interesante señalar que en el Bajo Papaloapan (Veracruz, México), la sociedad mesoamericana estableció una cosmovisión entre la naturaleza y el ser humano a partir de las divinidades creadoras y ordenadoras del caos, del equilibrio y del eterno ciclo de nacimiento y muerte. La naturaleza no sólo constituía parte del mundo místico, sino un componente integrador de su ser y consecución de la vida. La naturaleza era dadora de pasividad, pero también de turbulencia, estas sociedades reconocían en el agua una fuerza de equilibrio entre la vida y la muerte. (José Velasco toro, 2005, p.26).

Por lo tanto, las diversas culturas humanas han generado en su imaginación una explicación a la muerte y sus circunstancias, en los que se crean caminos, senderos, pasos y mundos en el más allá, una explicación a lo desconocido. Por ejemplo, en la antigua Grecia, la muerte tenía a menudo relación con el agua, como fin último, con su barquero Caronte, que atravesaba la laguna Estigia.

Al respecto Ana María Vázquez Hoys, (2007) afirma lo siguiente:

Un agua que puede destruir la identidad y fortalecerla, preserva la memoria o la aniquila, lleva a sus últimas consecuencias el carácter mortal y efímero del hombre o abre la puerta de su superación, en el centro del Aqueronte. En las corrientes estigias se produce una transformación que ilustra la iconografía de los difuntos, las pequeñas almas figuradas a veces o imágenes de los difuntos semidiluidas o semidesvanecidas, acompañadas de Hermes, el portador de almas, el Psicopompo. Pero los antiguos griegos, quizás acostumbrados a que el agua otorgase tanto riqueza como pobreza, fortuna 0 desesperación, prosperidad o fracaso, salvación o aniquilación, defendieron ese papel ambivalente del líquido al imaginarlo en los límites de la muerte (p.92).

\section{c) (i) (2) (2)}

La Revista Estudios es editada por la Universidad de Costa Rica y se distribuye bajo una Licencia Creative Commons Atribución-NoComercial-CompartirIgual 3.0 Costa Rica. Para más información envíe un mensaje a 
Por consiguiente, el agua para los griegos no solo simbolizaba fin sino transformación, cambio, dada por un ser que acompaña a las almas, es decir, una especie de psicopompo, término utilizado en diversas culturas para nombrar a ese ser. Esta voz proviene del griego, que se compone de psyche "alma" y "pompos" el que guía o conduce.

Como se observa la asociación del agua a la vida/muerte ha estado presente desde los orígenes de la humanidad y ha reconocido espacios simbólicos en la literatura universal. Las coplas de Manrique, por ejemplo, hacen alusión al agua como portadora de la muerte "Nuestras vidas son los ríos / que van a dar en la mar, / que es el morir; / allí van los señoríos / derechos a se acabar/ e consumir; / allí los ríos caudales, / allí los otros medianos / y más chicos, / y llegados, son iguales / los que viven por sus manos / y los ricos."

De igual forma, los estudios de Borges (1974) han señalado una ética y estética al respecto: "Mirar el río hecho de tiempo y agua / y recordar que el tiempo es otro río / saber que nos perdemos como el río / y que los rostros pasan como el agua. / Sentir que la vigilia es otro sueño / que sueña no soñar y que la muerte / que teme nuestra carne es esa muerte / de cada noche, que se llama sueño." (p.4)

En Borges el tiempo y el agua cobran semejanza, ambos simbolizan el fluir, la vida, lo efímero, y el estado último que es la muerte, muy similar al sueño.

Así, autores como Calderón de la Barca, García Lorca, Machado, entre otros cantaron al agua, metáfora predilecta en sus poemas como representaciones de fecundidad, amor, vida, infertilidad, muerte. La poesía de Marín abre espacios para el análisis y simbolismo en esta misma dirección.

Del poema "Heridas" cito:

\section{"Lentamente se deslizan}

\section{(c) (i) (9) (2)}

La Revista Estudios es editada por la Universidad de Costa Rica y se distribuye bajo una Licencia Creative Commons Atribución-NoComercial-Compartirlgual 3.0 Costa Rica. Para más información envíe un mensaje a revistaestudios.eeg@ucr.ac.cr. 
Especial: Naturaleza amena y naturaleza agreste en las letras hispánicas

por mi pecho y mi cordura

las espadas invencibles

que desangran mis arterias,

entregándome la carga

de sus gotas infecundas

en el cause que galopa

tras la fuente de burbujas

¡me detengo en los enjuagues

de las aguas y las perlas

recibiendo los ocasos

las penurias y las sombras!" (p.83)

El sujeto lírico establece semejanza de las heridas con el paso del tiempo, con el cause y con lo infecundo, es decir la aproximación a la muerte del ser como estado final. Para Gastón Bachelard (1978) el agua va más allá de la imaginación, es cambio, transformación, metamorfosis, intimidad y destino. No esta simplemente en el estado de la ensoñación, el agua es sustancia y fin. Por lo tanto, la obra de Marín revela el ciclo natural de la vida, una vida condicionada al tiempo y en concreta concordancia con la muerte, fin, estado último. La vejez, por ende, salta en los versos como portadora del encuentro con las aguas en "descendentes laderas" como lo señala el poema "Sueño vencido". La metáfora está construida precisamente de ese encuentro de la muerte con el agua.

"Me llegan apresurados

los huertos de mil verdades, sin invencibles arados se labran mis senectudes

Cuando aparece el agobio tendido sobre mi fosa, vertiendo mis ilusiones

\section{(c) (i) (-)}

La Revista Estudios es editada por la Universidad de Costa Rica y se distribuye bajo una Licencia Creative Commons Atribución-NoComercial-CompartirIgual 3.0 Costa Rica. Para más información envíe un mensaje a revistaestudios.eeg@ucr.ac.cr. 
ISSN 1659-3316

Diciembre 2018

Especial: Naturaleza amena y naturaleza agreste en las letras hispánicas

Por lo tanto, debo concluir que la obra de Marín encierra de manera clara un acercamiento al simbolismo del agua como proceso y una relación predominante con la vida/la muerte. Es el poemario en sí un largo canto a la vejez, casi como una copla, a la manera de Jorge Manrique, es decir, un grito de desesperanza, un largo lamento. Hay reconocimiento del yo lírico del paso de la vida que como el agua no puede detenerse, por tanto, el agua es irremediablemente sustancia de vida/muerte. 


\section{REFERENCIAS BIBLIOGRÁFICAS}

Alonso Eva et al (2016). ¿Existen los símbolos del agua en el inconsciente? Cantabria, España.

Atadía, Pablo (2015). El agua, el espejo y la sombra- Carl Gustav Jung.

Bachelard, Gastón. (1997) El agua y los sueños. México. F.C.E.

Basualto, María Alexandra (1984). Simbología del agua en la poesía de Miguel Artreche. Tesis doctoral. Chile.

Borges, J. (1977). Obra poética. Buenos Aires: Emencé Editores.

Eliade, Mircea. (1978) Historia de las creencias y de las ideas religiosas. I: De la prehistoria a los misterios de Eleusis, Cristiandad, Madrid.

Marín Guzmán Jorge (2014). Pleamar de Vejez. Editorial Mirambell,S.A. Costa Rica. López-Casanova, Arcadio. (1994). El texto poético. Teoría y metodología. Salamanca: Ediciones.

Vázquez Hoys, Ana María (2005) Un universo de agua. UNED, Madrid.

Velasco toro, José (2005). "Símbolo de vida y muerte en el Bajo Papaloapan”. En: Innundaciones en Veracruz, México.

Real Academia Española de la Lengua (2016). Diccionario de la lengua. Espasa libros, Madrid.

\section{(C) $(00$}

La Revista Estudios es editada por la Universidad de Costa Rica y se distribuye bajo una Licencia Creative Commons Atribución-NoComercial-CompartirIgual 3.0 Costa Rica. Para más información envíe un mensaje a 